Pesq. Vet. Bras. 35(3):230-236, março 2015

DOI: $10.1590 / \mathrm{S} 0100-736 \mathrm{X} 2015000300004$

\title{
Effects of intramammary infection on whey proteinograms of sheep during lactation ${ }^{1}$
}

\author{
Vânia F. Lemos², Eduardo L.S. Guaraná ${ }^{3}$, José A.B. Afonso ${ }^{4}$, José J. Fagliari ${ }^{5}$, \\ Paulo C. Silva ${ }^{5}$, Pierre C. Soares ${ }^{6}$ and Carla Lopes de Mendonça ${ }^{4 *}$
}

\begin{abstract}
Lemos V.F., Guaraná E.L.S., Afonso J.A.B., Fagliari J.J., Silva P.C., Soares P.C. \& Mendonça C.L. 2015. Effects of intramammary infection on whey proteinograms of sheep during lactation. Pesquisa Veterinária Brasileira 35(3):230-236. Clínica de Bovinos, Universidade Federal Rural de Pernambuco, Campus Garanhuns, Av. Bom Pastor s/n, Cx. Postal 152, Boa Vista, Garanhuns, PE 55292-270, Brazil. E-mail: carlalopes.mendonca@gmail.com

The study aimed to identify potential biomarkers of mammary gland infection in Santa Inês sheep. Commercial flocks of sheep provided the same hygiene, sanitary, and nutritional management under semi-intensive production systems were monitored during the lactation stage-and assessed 15, 30, 60, and 90 days after delivery (through the end of lactation and weaning). The California Mastitis Test (CMT) was performed on the mammary glands. Milk was collected for bacterial examination and protein analysis. Bacterial culture and biochemical characterization of the samples were performed. Forty-two milk samples from healthy glands (negative CMT and bacterial testing) and 43 milk samples from infected glands (positive CMT and bacterial testing) taken at the predefined time points were assessed. A rennin solution was used to obtain the whey. The proteins analysis was performed using sodium dodecyl sulfate-polyacrylamide gel electrophoresis (SDS-PAGE), which allowed for the quantification of nine whey proteins produced in healthy glands: serum albumin, lactoferrin, IgA, IgG heavy-chain (IgG HC), IgG light-chain (IgG LC), total IgG (IgG HC + IgG LC), $\alpha$-lactalbumin, $\beta$-lactoglobulin, protein with MW $15.000 \mathrm{Da}$, protein with MW 29.000 Da and eleven whey proteins secreted by infected glands, including haptoglobin and $\alpha$-1-acid glycoprotein. A comparison of whey proteins between healthy and infected glands showed increases $(\mathrm{P}<0.05)$ in the secreted and total contents of all proteins, except for IgG LC and $\alpha$-lactoalbumin. The most significant changes were observed in $\alpha$-1acid glycoprotein, lactoferrin and haptoglobin, which showed three-, five-, and seven-fold increases in secretion, respectively. This study showed that haptoglobin, $\alpha-1$-acid glycoprotein, lactoferrin, albumin, and the IgA and IgG immunoglobulins may serve as potential biomarkers for mammary gland infection in sheep.
\end{abstract}

INDEX TERMS: Subclinical mastitis, ewes, milk, acute-phase protein, biomarkers.

RESUMO.- [Efeitos da infecção intramamária no proteinograma de ovinos durante a lactação.] Este estudo teve como objetivo identificar potenciais biomarcadores de infecção na glândula mamária de ovelhas Santa Inês. Foram

\footnotetext{
${ }^{1}$ Received on August 12, 2014.

Accepted for publication on February 10, 2015

${ }^{2}$ Programa de Pós-Graduação em Sanidade e Reprodução de Ruminantes, Universidade Federal Rural de Pernambuco (UFRPE), Av. Bom Pastor s/n, Cx. Postal 152, Boa Vista, Garanhuns, PE 55292-270, Brazil. E-mail: vanialemos91@gmail.com

${ }^{3}$ Programa de Pós-Graduação em Ciência Veterinária, UFRPE, Av. Dom Manoel de Medeiros s/n, Dois Irmãos, Recife, PE 52171-900, Brazil.
}

monitorados rebanhos comerciais de ovinos, submetidos ao mesmo manejo higiênico-sanitário e nutricional, criados em sistemas de produção semi-intensivo durante as várias fases de lactação e avaliados aos 15, 30, 60 e 90 dias após

\footnotetext{
${ }^{4}$ Clínica de Bovinos, UFRPE, Campus Garanhuns, Av. Bom Pastor s/n, Cx. Postal 152, Boa Vista, Garanhuns, PE 55292-270.*Corresponding author: carlalopes.mendonca@gmail.com

${ }^{5}$ Departamento de Clínica e Cirurgia, Faculdade de Ciências Agrárias e Veterinárias, Universidade Estadual Paulista (Unesp), Via de acesso Prof. Paulo Donato Castellane s/n, Jaboticabal, SP 14884-900, Brazil.

${ }^{6}$ Departamento de Medicina Veterinária, UFRPE, Av. Dom Manoel de Medeiros s/n, Dois Irmãos, Recife, PE 52171-900.
} 
o parto (até o final da lactação e desmame). Realizou-se o California Mastit Test (CMT). 0 leite foi coletado para análise bacteriana e análise de proteínas. Foi realizada a cultura bacteriana e a caracterização bioquímica das amostras. Foram selecionadas 42 amostras de leite provenientes de glândulas sadias (CMT negativo e teste bacteriológico negativo) e 43 amostras de leite de glândulas infectadas (CMT positivo e teste bacteriológico positivo). 0 soro lácteo foi obtido por meio da adição de renina. A proteína total no soro lácteo foi mensurada utilizando o método do biureto e a identificação das proteínas empregando-se eletroforese em gel de poliacrilamida com dodecil sulfato de sódio (SDS-PAGE), permitindo a quantificação de nove proteínas no soro lácteo das glândulas sadias: albumina, lactoferrina, IgA, IgG de cadeia pesada (IgG CP), IgG de cadeia leve (IgG CL), a IgG total (IgG CP+ IgG CL), $\alpha$-lactalbumina, $\beta$ lactoglobulina, proteína de PM $15.000 \mathrm{Da}$, proteína de PM 29.000 Da. No soro das glândulas infectadas foram identificadas onze proteínas, incluindo além das citadas acima a haptoglobina e $\alpha-1$ glicoproteína ácida. Na comparação das proteínas do soro lácteo de glândulas sadias e infectadas observou-se aumento $(\mathrm{P}<0,05)$ em todas as proteínas, com exceção de IgG CL e $\alpha$-lactoalbumina. As alterações mais expressivas foram observadas nas concentrações de $\alpha 1$-glicoproteína ácida, lactoferrina e haptoglobina, que demostraram aumentos de três, cinco e sete vezes, respectivamente. Este estudo demonstrou que a haptoglobina, $\alpha$-1-glicoproteína ácida, lactoferrina, albumina e as imunoglobulinas IgA e IgG podem ser caracterizadas como potenciais marcadores para a infecção da glândula mamaria em ovelhas.

TERMOS DE INDEXAÇÃO: Mastite subclínica, ovelhas, leite, proteína de fase aguda, marcadores biológicos.

\section{INTRODUCTION}

Mastitis is one of the most economically important diseases in sheep, and it is responsible for significant costs in sheep husbandry. Santa Inês sheep, which are generally raised using semi-intensive and intensive management systems that include a richer diet, have a greater tendency to develop mammary glands infections, especially when their surplus milk is not consumed by their lambs (Kirk \& Glenn 1996, Oliveira 2006).

Macroscopic changes to the udder and milk secretion are not typically observed in subclinical mastitis; however, a decrease in milk production, changes in the physical and chemical composition of the milk, an increase in the number of somatic cells, and the isolation of microorganisms, are often observed, all of which induce a loss of productivity in flock and compromise lamb nutrition (Naccari et al. 2003, Anderson et al. 2005, Santos et al. 2007, Leitner et al. 2012). Subclinical mastitis usually leads to clinical mastitis, which is caused by the same etiologic agents and is one of the most common reasons for the culling of breeding animals, thus decreasing flock productivity (Menzies \& Ramanoon 2001, Oliveira 2006).

Several systemic responses occur during the initial stages of infection, including those known as acute-phase responses (Eckersall 2008, Costa et al. 2010). The concen- tration of acute-phase proteins in milk may increase or decrease in the presence of an inflammatory process and are therefore recognized as biomarkers for inflammation and/ or infection (Eckersall \& Bell 2010).

Diagnosis of mastitis in sheep is based on clinical examination, somatic cell count, and bacterial analysis of the milk. A faster and less severe diagnosis often leads to immediate treatment and a shorter recovery time. With the implementation of mechanized production systems, the demand for fast and accurate biomarkers for mastitis has significantly increased. Several studies have suggested that acute-phase proteins could serve as reliable indicators of an inflammatory process in the mammary gland (Hirvonen et al. 1996, Eckersall et al. 2001, Costa et al. 2010, Ceciliani et al. 2012). The adoption of tools for the close monitoring of flock hygiene may be useful in sanitary programs, although this often requires knowledge of potential biomarkers for health and disease (Ganheim et al. 2007). The concentrations of whey proteins may vary considerably during mammary gland inflammation, even in the absence of changes in the total protein concentration in the milk (Schalm et al. 1971, Auldist et al. 1995, Sant'ana 2004).

The objective of the present trial was to identify potential biomarkers of mammary gland infection in Santa Inês sheep.

\section{MATERIALS AND METHODS}

Santa Inês sheep from a local commercial flock were monitored. The sheep were raised under a semi-intensive system, subjected to the same hygiene, sanitary and nutritional management schemes, and assessed at different lactation stages (beginning, middle and end of lactation, in 90 days, which the set time for weaning in the region).

The clinical examination of the animals and their mammary glands followed the recommendations by Diffay et al. (2005). The results of the California Mastitis Test (CMT) were classified as negative (negative reaction or trace amounts) or positive $(1+, 2+$, or 3+) (Schalm et al. 1971). Assessments were conducted for 42 samples from healthy glands (negative CMT/negative bacterial test) and for 43 samples from infected glands (positive CMT/positive bacterial test). About $10 \mathrm{~mL}$ of milk was collected to perform the protein analysis and $5 \mathrm{~mL}$ for bacterial culture. The study was approved by the Animal Ethics Committee (CEUA) of the Rural Federal University of Pernambuco under License No. 017/2010 (6029/2010 D08 CEPE/UFRPE) according to the COBEA (Colégio Brasileiro de Experimentação Animal) and the National Institutes of Health Guide for the Care and Use of Laboratory Animals guidelines.

Bacterial cultures were established according to the recommendations of the National Mastitis Council (1990), and biochemical characterization was performed according to Quinn et al. (1994). For protein analysis, whey was collected according to Schalm et al. (1971), with minor modifications due to the small volume of milk produced by the sheep. The milk samples were homogenized and for each $1000 \mu \mathrm{L}$ of milk, $75 \mu \mathrm{L}$ of rennin solution was added. The samples were incubated in water bath at $37^{\circ} \mathrm{C}$ for approximately $20 \mathrm{~min}$ until clot formation. Subsequently, the samples were centrifuged at $21000 \times g$ for $10 \mathrm{~min}$ in a refrigerated centrifuge. Following centrifugation, the whey samples corresponding to the intermediate fraction of the three-phase solution were collected by aspiration and stored in an ultra-low temperature freezer at $-80^{\circ} \mathrm{C}$ for later analysis. The determination of the 
total protein in whey was performed using the biuret method, observing its linearity, and considering the smaller amount of total protein compared to that in blood serum.

Separation of the protein fractions was achieved by SDS-PAGE, as described by Laemmli (1970) and Fagliari \& Silva (2002). Protein concentrations were measured using a computerized densitometer. To identify protein fractions in whey, a marker solution with different molecular weights (6.500-200.000 Da), as well as purified bovine lactoferrin, $\beta$-lactoglobulin, and $\alpha$-lactalbumin was used as reference (Sigma Marker).

The results, which were blinded to normality assumptions by applying the Kolmogorov-Smirnov test, were subjected to base ten logarithmic transformation and ANOVA using the GLM procedure in the SAS (Statistical Analysis Systems Institute Inc) program. The means were compared using the minimum significant difference (m.s.d.) of the Student-Newman-Keuls (SNK) test at a significance level of 5\%. The albumin, IgG heavy chain (IgG HC), IgG light chain (IgG LC), total IgG, MW 29.000 Da protein, and lactoferrin were subjected to logarithmic transformation, whereas haptoglobin, $\alpha$-1-acid glycoprotein (AGP), and MW 15.000 Da protein were subjected to Wilcoxon's non-parametric test, with data expressed as medians and percentiles $\left(\mathrm{P}_{25}\right.$ and $\left.\mathrm{P}_{75}\right)$ (Sampaio 2007).

\section{RESULTS}

Electrophoretic fractionation allowed the identification and/or quantification of proteins in the whey collected from healthy mammary glands, namely, lactoferrin (Fig.1)., albumin (Fig.2), IgA (Fig.3), IgG HC (Fig.3), IgG LC (Fig.3), $\beta$ lactoglobulin (Fig.4), $\alpha$-lactalbumin (Fig.5), and two other proteins identified as having MWs of 15.000 Da (Fig.6), and 29.000 Da. (Fig.7). In the whey from infected glands (subclinical mastitis cases), all of these proteins were observed, in addition to haptoglobin and $\alpha-1$-acid glycoprotein (Table 1).

\section{DISCUSSION}

Total protein. Significantly different total protein concentrations were observed in the whey from healthy and infected glands $(\mathrm{P}<0.0001)$ (Table 1, Fig.8). The increase in whey protein content in glands undergoing inflammation may be attributed to the higher protein transudation from the blood, which is a consequence of the increase in vascular permeability, subclinical or clinical mastitis is associated with an increase in the total protein concentration in milk, which results from the passage of higher concentrations of immunoglobulins and albumin from the blood in to the milk (Paape et al. 1995). Total whey protein concentrations in sheep mammary glands with higher somatic cell counts have been recently reported by Summer et al. (2012).

An elevation of the whey protein concentration in cows afflicted with mastitis was reported previously by Sant'ana (2004), however, Raimondo et al. (2011) observed no change in milk protein concentration in goats with mastitis indicating that bacterial infection does not influence this variable.

Albumin. Albumin levels were significantly higher $(\mathrm{P}<0.0001)$ in infected glands than in healthy glands (Table 1, Fig.2), thus confirming an increase in vascular permea- bility and the passage of blood albumin to the mammary glands (Paape et al. 1995, Shirazi-Beheshtiha 2012). This observation may also be attributable to the production of albumin by the gland itself, as observed by Shamay et al. (2005), suggesting that albumin secretion in the mammary gland is part of a non-specific defense system.

Immunoglobulins. The concentrations of IgA, total IgG $(\operatorname{IgG} \mathrm{HC} / \operatorname{IgG} \mathrm{LC})(\mathrm{P}<0.0006)$ and heavy chain IgG $(\mathrm{P}<0.0002)$ were significantly higher $(0.0001)$ in infected glands, whereas the light chain IgG concentrations were not significantly different $(P>0.5350)$ between infected and healthy glands (Table 1, Fig.3). The mean concentration of

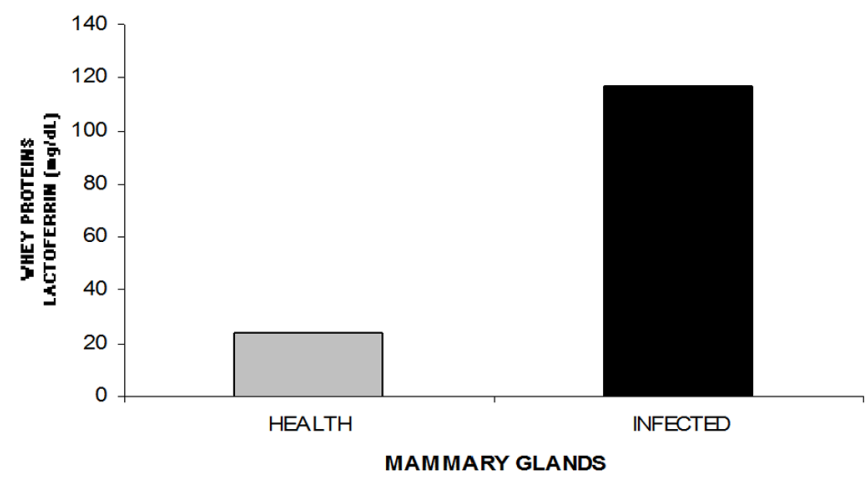

Fig.1. Mean values of lactoferrin concentration from sheep healthy and infected mammary glands during lactation.

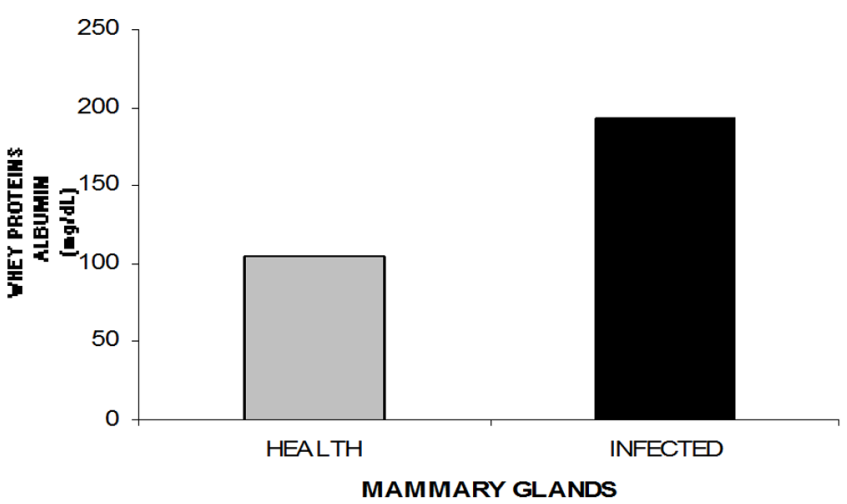

Fig.2. Mean values of albumin concentration from sheep healthy and infected mammary glands during lactation.

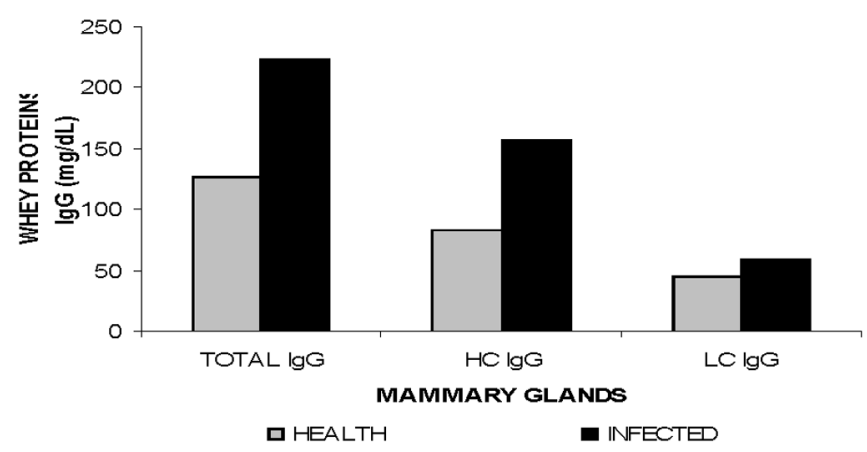

Fig.3. Mean values of total IgG, IgG heavy chain and light chain IgG whey from healthy and infected mammary glands of Santa Inês sheep during lactation. 


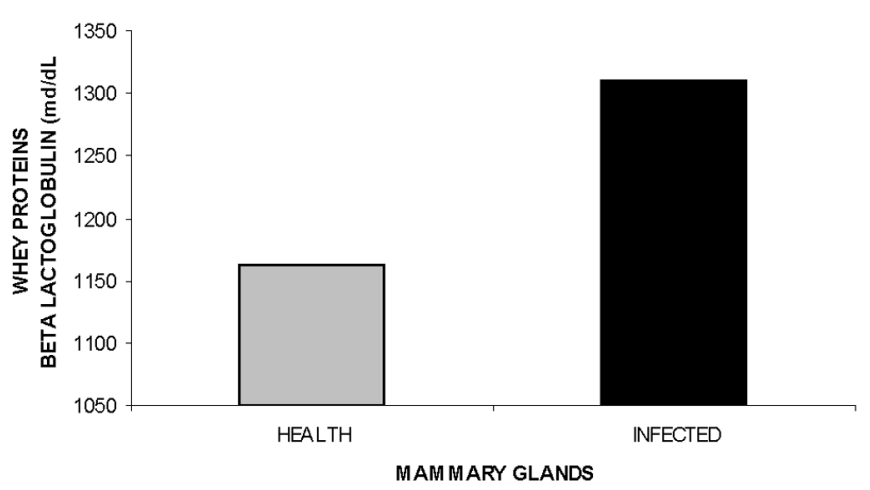

Fig.4. Mean values of $\beta$ lactoglobumin concentration from sheep healthy and infected mammary glands during lactation.

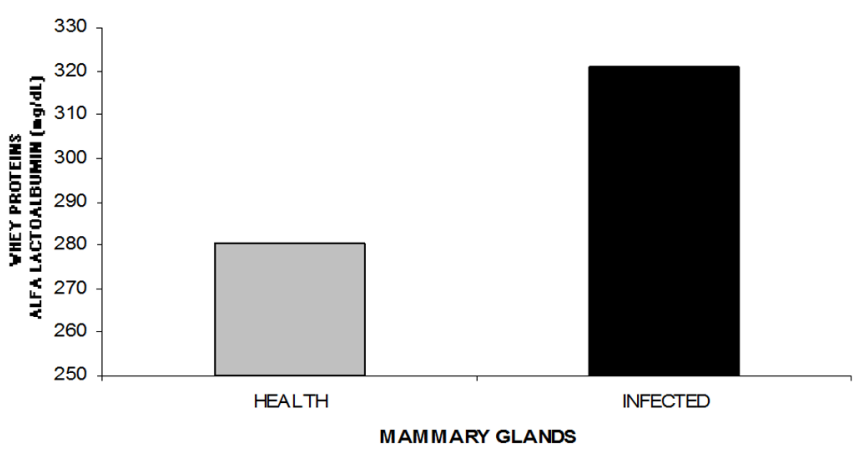

Fig.5. Mean values of $\alpha$-lactalbumin from sheep healthy and infected mammary glands during lactation.

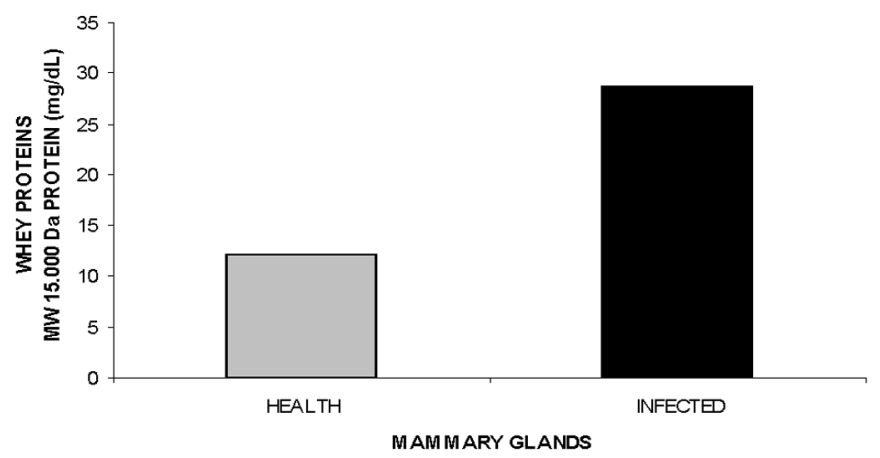

Fig.6. Mean values of MW 15.000 Da from sheep healthy and infected mammary glands during lactation.

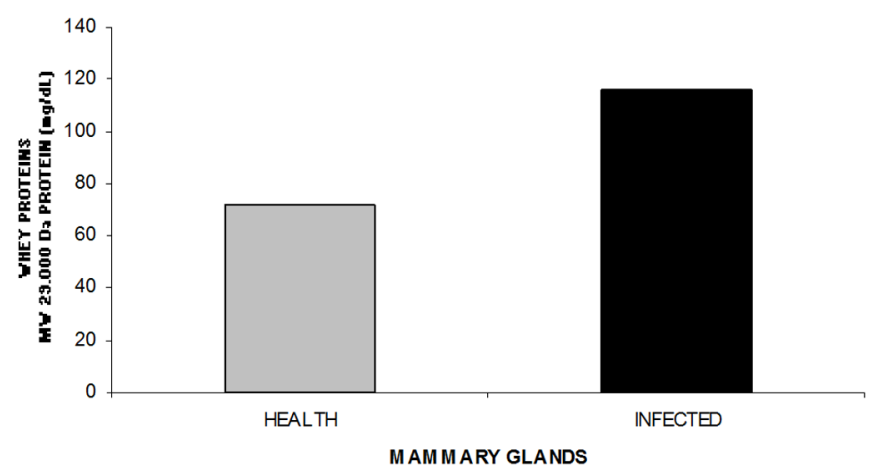

Fig.7. Mean values of MW 29.000 Da from sheep healthy and infected mammary glands during lactation.
IgA secreted by glands with subclinical mastitis $(6.07 \mathrm{mg} /$ $\mathrm{dL}$ ) was almost three times higher than the concentration in healthy glands $(2.72 \mathrm{mg} / \mathrm{dL})$. In addition, the level of secreted IgG was two-fold higher in infected glands. These results suggest that during mammary gland inflammation, immunoglobulins produced in response to antigenic stimuli migrate from the blood to the milk as a defense mechanism of the compromised gland, similar to what is observed in cows (Urech \& Puhan 1999, Mehra et al. 2006, Eckersall 2008).

Lactoferrin. The mean lactoferrin concentration in infected glands was 4.8 times higher than that in healthy glands $(\mathrm{P}<0.0001)$ (Table 1, Fig.1), showing that this protein plays a role in the natural defense mechanisms against mammary gland inflammation in sheep, as well as in cows. This response serves as the first barrier against infectious agents, particularly bacteria, due to the ability of lactoferrin to capture iron ions, rendering them unavailable as a nutrient source for bacterial growth and their possible expression of more pathogenic traits (Harmon et al. 1976, Smith \& Schanbacher 1977, Hagiwara et al. 2002).

Similar results have been reported by Nudda et al. (2003), who observed a two-fold increase in lactoferrin concentrations in whey samples from sheep with somatic

Table 1. Mean values, standard deviations, medians, percentiles $\left(P_{25}\right.$ and $\left.P_{75}\right)$ and significance levels of the protein concentration $(\mathrm{mg} / \mathrm{dL})$ identified in the whey of Santa Inês sheep in healthy and infected mammary glands

\begin{tabular}{lccc}
\hline Proteins & \multicolumn{2}{c}{ Mammary gland } & Pr $>$ F \\
\cline { 2 - 3 } & Healthy & Infected & \\
\hline PT (g/dL) & $1,81 \pm 0,20^{\mathrm{b}}$ & $2,56 \pm 1,01^{\mathrm{a}}$ & 0,0001 \\
IgA & $2,72 \pm 1,87^{\mathrm{b}}$ & $6,07 \pm 2,98^{\mathrm{a}}$ & 0,0001 \\
Albumin & $104,94 \pm 48,90^{\mathrm{b}}$ & $193,57 \pm 190,11^{\mathrm{a}}$ & 0,0001 \\
IgG HC & $83,04 \pm 46,71^{\mathrm{b}}$ & $156,69 \pm 139,32^{\mathrm{a}}$ & 0,0002 \\
IgG LC & $45,00 \pm 24,79^{\mathrm{a}}$ & $59,48 \pm 69,28^{\mathrm{a}}$ & 0,5350 \\
IgG Total & $126,56 \pm 59,19^{\mathrm{b}}$ & $222,85 \pm 154.68^{\mathrm{a}}$ & 0,0006 \\
Lactoferrin & $24,18 \pm 11,33^{\mathrm{b}}$ & $117,09 \pm 115,56^{\mathrm{a}}$ & 0,0001 \\
$\alpha$ - lactoalbumin & $280,25 \pm 107,57^{\mathrm{a}}$ & $321,07 \pm 133,67^{\mathrm{a}}$ & 0,1252 \\
$\beta$ - lactoglobulin & $1162,47 \pm 166,56^{\mathrm{b}}$ & $1310,96 \pm 228,48^{\mathrm{a}}$ & 0,0010 \\
MW 15.000 Da & $12,10(8,46 ; 15,07)^{\mathrm{b}}$ & $28,65(14,79 ; 73,16)^{\mathrm{a}}$ & 0,0091 \\
MW 29.000 Da & $71,61 \pm 42,04^{\mathrm{b}}$ & $115,93 \pm 79,96^{\mathrm{a}}$ & 0,0002 \\
Haptoglobin & $0,00(0,0 ; 0,0)^{\mathrm{b}}$ & $7,04(4,12 ; 12,50)^{\mathrm{a}}$ & 0,0001 \\
$\alpha-1$ AGP & $0,00(0,0 ; 0,0)^{\mathrm{b}}$ & $3,99(3,26 ; 7,24)^{\mathrm{a}}$ & 0,0001
\end{tabular}

Different letters in superscript indicate a significant difference between health and infected mammary glands.

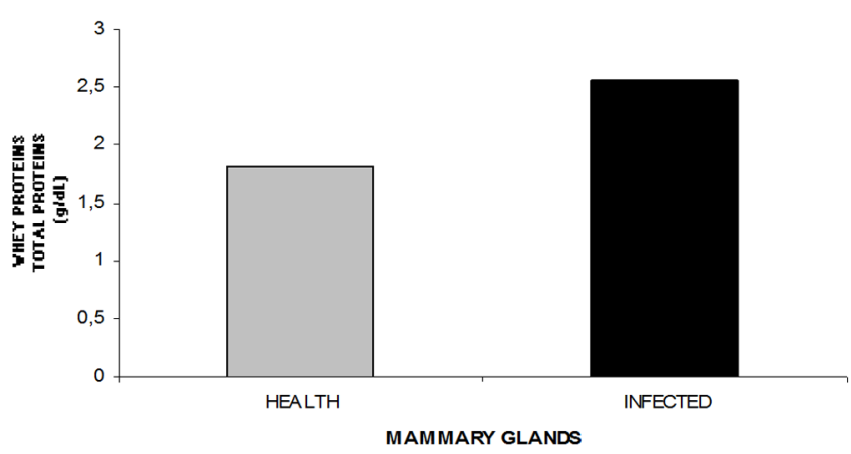

Fig.8. Mean values of whey total protein concentration from sheep healthy and infected mammary glands during lactation. 
cell counts above one million. Sant'ana (2004) also reported a two-fold increase in lactoferrin concentration in cows with mastitis, and Raimondo et al. (2011) reported a significant increase in lactoferrin concentration in goats with mastitis, highlighting the precociousness of its appearance compared to that of other whey proteins.

Hagiwara et al. (2002) showed that lactoferrin concentrations could serve as indicators of the pathogenicity of the bacterial species involved, in which higher concentrations of lactoferrin indicate greater bacterial pathogenicity. Lactoferrin could also modify cell membrane permeability in some bacteria, preventing their growth upon the secretion of lactoferrin from the secondary granules of neutrophils during inflammation (Harmon et al. 1976, Smith \& Schanbacher 1977, Rainard 1986, Farrell et al. 2004, Komine et al. 2006, Conesa et al. 2008).

$\boldsymbol{\alpha}$-Lactalbumin. No significant differences in $\alpha$-lactalbumin levels were observed between healthy and infected glands, which measured $280.25 \mathrm{mg} / \mathrm{dL}$ and 321.07 $\mathrm{mg} / \mathrm{dL}$, respectively (Table 1, Fig.5). Although not statistically significant $(P>0.1252)$, these results showed an elevated $\alpha$-lactalbumin concentration in infected glands, thus supporting the findings of Sant'ana (2004), who used whey samples from cows. Nudda et al. (2003) also observed a significant increase in this protein fraction in relation to an increase in somatic cell counts in sheep with mastitis. However, these results contradict the observations of Raimondo et al. (2011), who observed a decrease in $\alpha$-lactalbumin values in cases of mastitis in goats, and also those by Bortree et al. (1962), Schalm et al. (1971), Harmon et al. (1976), and Prosser \& McLaren (1997), who described an association between a decrease in $\alpha$-lactalbumin and a decrease in lactose in mastitis cases. However, this association between a decrease in $\alpha$-lactalbumin and the presence of mastitis was studied in cows, and the methodology used for their analyses was different from that used in this study.

$\boldsymbol{\beta}$-Lactoglobulin. A significant increase $(\mathrm{P}<0.0001)$ in $\beta$-lactoglobulin concentration was observed in infected glands compared to that in healthy ones (Table 1, Fig.4), which is in agreement with the results of Nudda et al. (2003), who observed significant increases in $\beta$-lactoglobulin in the whey of sheep with mastitis with somatic cell counts higher than 1.000.000. These results differ from that reported in other studies involving ruminants. For example Sant'ana (2004) did not observe significant changes in the whey proteinogram of cows with mastitis, whereas Raimondo et al. (2011) observed a decrease in $\beta$-lactoglobulin in goats with mastitis. The increase in $\beta$-lactoglobulin in infected sheep mammary glands may be attributable to its actual concentration rather than to increased production because less milk is generally produced during mastitis (Nudda et al. 2003).

MW 15.000 Da and MW 29.000 Da proteins. Significant differences in the concentrations of the MW 15.000 Da and MW 29.000 Da proteins $(\mathrm{P}<0.0001$ and $\mathrm{P}<0.0002$, Fig.6, Fig.7, respectively, Table 1) were observed, with 1.6 and 2.4 fold increases, respectively, in infected mammary glands. Further characterization and functional studies are warranted for these two proteins. $\alpha$-1-acid glycoprotein/haptoglobin. This study highlighted $\alpha$-1-acid glycoprotein and haptoglobin as part of the acute inflammatory phase in whey because these are exclusively detected in infected glands $(\mathrm{P}<0.0001)$, with a four and seven fold increase in concentration, respectively, observed in infected mammary glands (Table 1, Fig.9).

The $\alpha$-1-acid glycoprotein is an important acute inflammatory phase protein, often used in monitoring infections (Eckersall et al. 2001). It is considered a moderate acutephase protein that gradually increases in concentration; however, its levels remain high for a longer period compared to other acute-phase proteins. Therefore, it is considered a chronic marker for inflammation (Eckersall 2008, Ceciliani et al. 2012).

This protein is normally identified in whey, however, its presence in sheep whey has not been reported in the literature. We believe that it is linked to the inflammatory process of the mammary gland because it has been identified only in infected glands. Its extra-hepatic productions has been reported previously in the epithelial cells of the mammary glands of humans and cattle (Ceciliani et al. 2005, Rainard \& Riollet 2006, Ceciliani \& Pocacqua 2007).

Although the precise role of the $\alpha-1$ - acid glycoprotein remains elusive, studies suggest that it binds to a series of endogenous metabolites at the site of inflammation and acts on the innate immune response against infections thus modulating the immune reaction through the inhibition of phagocytosis, neutrophils activation, and platelet aggregation (Ceciliani \& Pocacqua 2007, Eckersall 2008). Activated leukocytes may also act as a local source of $\alpha-1$-acid glycoprotein, which facilitates the rapid generation of an immunological defense against damage caused by inflammation (Ceciliani \& Pocacqua 2007).

Haptoglobin has also been detected in the whey of infected glands. Haptoglobin levels are usually very low or undetectable; however, in cases of inflammation or infection in ruminants, the haptoglobin concentration may significantly increase (Eckersall et al. 2001). Haptoglobin generally appears in the plasma, but may also be present in milk, urine, and saliva (González et al. 2007). Some researchers have reported elevations in haptoglobin concentrations, both in blood plasma and in milk, in cows with clinical and subclinical mastitis (Eckersall et al. 2001, Grön-

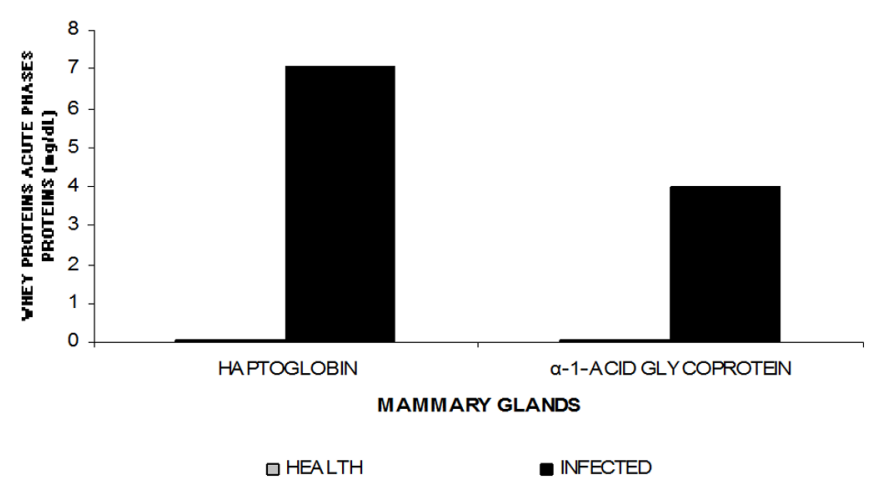

Fig.9. Mean values of haptoglobin and $\alpha 1$ acid glycoprotein from sheep healthy and infected mammary glands during lactation. 
lund et al. 2005, González et al. 2007, Pyörala et al. 2011), suggesting its potential as a biomarker for mammary gland inflammation. The detection of elevated haptoglobin levels in infected mammary glands is related to its extra-hepatic secretion by mammary tissue cells (Akerstedt et al. 2007) and its ability to bind to molecules produced in damaged tissues, resulting in the inaccessibility of iron to bacteria, which limit bacterial proliferation (Suojala et al. 2008).

\section{CONCLUSION}

The whey proteins haptoglobin, $\alpha$-1-acid glycoprotein, lactoferrin, albumin IgA and IgG are potential biomarkers of mammary gland inflammation in sheep, especially the two first proteins.

Acknowledgements.- The authors acknowledge the contribution of the National Council of Scientific and Technological Development (CNPq) for financial support and the Coordination for the Improvement of Higher Education Personnel (CAPES) for the award of the Social Demand.

\section{REFERENCES}

Anderson D.E., Hull B.H. \& Pugh D.G. 2005. Enfermidades da glândula mamária, p.379-399. In: Pugh D.G. (Ed.), Clínica de Ovinos e Caprinos. Roca, São Paulo

Akerstedt M., Waller K.P. \& Sternesjo A. 2007. Haptoglobin and serum amyloid A in relation to the somatic cell count in quarter, cow composite and bulk tank milk samples. J. Dairy Res. 74:198-203.

Auldist M.J., Coats S., Rogers G.L. \& McDowell G.H. 1995. Changes in the composition of milk from healthy and mastitic dairy cows during the lactation cycle. Aust. J. Exp. Agricult. 35:427-436.

Bortree A.L., Carroll E.J. \& Schalm 0. 1962. Whey protein patterns of milk from cows with experimentally produced mastitis. J. Dairy Sci. 45:1465.

Ceciliani F., Pocacqua V., Provasi E., Comunian C., Bertolini A., Bronzo V., Moroni P. \& Sartorelli P. 2005. Identification of the bovine $\alpha 1$-acid glycoprotein in colostrum and milk. Vet. Res. 36:735-746.

Ceciliani F. \& Pocacqua V. 2007. The acute phase protein $\alpha-1$ glycoprotein: a model for altered glycosylation. Curr. Protein Pept. Sci. 8:91-108.

Ceciliani F., Ceron J.J., Eckersall P.D. \& Sauerwein H. 2012. Acute phase proteins in ruminants- Review. J. Proteomics 75:4207-4231.

Conesa C., Sánchez L., Rota C., Péreza M.-D., Calvo M., Farnaud S. \& Evans R.W. 2008. Isolation of lactoferrin from milk of different species: calorimetric and antimicrobial studies. Comp. Biochem. Physiol. 150:131139.

Costa N.A., Simão L.C., Santos R.A., Afonso J.A.B., Fagliari J.J., Cardoso E.C.C., Soares P.C. \& Mendonça C.L. 2010. Proteinograma e teores de cobre, ferro e zinco no soro de ovelhas da raça Santa Inês com mastite experimental por Staphylococcus aureus. Pesq. Vet. Bras. 30:435-442.

Diffay B.C., McKenzie D., Wolf C. \& Pugh D.G. 2005. Abordagem e exame de ovinos e caprinos, p.1-19. In: Pugh D.G. (Ed.), Clínica de Ovinos e Caprinos. Roca, São Paulo.

Eckersall P.D., Young F.J., McComb C., Hogarth C.J., Safi S., Weber A., McDonald T., Nolan A.M. \& Fitzpatrick J.L. 2001. Acute phase protein in serum and milk from dairy cows with clinical mastitis. Vet. Rec. 148:35-41.

Eckersall P.D. 2008. Proteins, proteomics, and the dysproteinemia, p.117155. In: Kaneko J.J., Harvey J.W. \& Bruss M.L. (Eds), Clinical Biochemistry of Domestic Animals. 6th ed. Academic Press, San Diego.

Eckersall P.D. \& Bell R. 2010. Biomarkers of infection and inflammation in veterinary medicine. Vet. J. 185:23-27.

Fagliari J.J. \& Silva S.L. 2002. Hemograma e proteinograma plasmático de equinos hígidos e de equinos acometidos por abdômem agudo antes e após laparotomia. Arq. Bras. Med. Vet. Zootec. 54:559-586.

Farrell Jr H.M., Jimenez-Flores R.G.T., Bleck G.T., Brown E.M., Butler J.E., Creamer L.K., Hicks C.L., Hollar C.M., Ng-Kwai-Hang K.F. \& Swaisgood
H.E. 2004. Nomenclature of the proteins of cows' milk-Sixth revision. J. Dairy Sci. 87:1641-1674.

Ganheim C., Alenius S. \& Waller K.P. 2007. Acute phase proteins as indicators of calf herd health. Vet. J. 173:645-651.

González F.H.D., Martínez-Subiela S. \& Cerón J.J. 2007. Haptoglobina em rumiantes: generalidades y posibles aplicaciones clínicas. An. Vet. Murcia 23:5-17.

Grönlund U., Sandgren C.H. \& Maller K.P. 2005. Haptoglobin and serum amyloid A in milk from dairy cows with chronic sub-clinical mastitis. Vet. Res. Les Ulis 36:191-198.

Hagiwara S., Kawai K., Anari A. \& Nagahata H. 2002. Lactoferrin concentrations in milk from normal and subclinical mastitic cows. J. Vet. Med. Sci. 65:319-323.

Harmon R.J., Schanbacher F.L., Ferguson L.C. \& Smith K.L. 1976. Changes in lactoferrin, immunoglobulin G, bovine serum albumin, and alpha-lactalbumin during acute experimental and natural coliform mastitis in cows. Infect. Immun. 13:533-542.

Hirvonen J., Pyorala S. \& Jousimies-Somer H. 1996. Acute response in heifers with experimentally induced mastitis. J. Dairy Sci. 63:351-360.

Kirk J.H. \& Glenn J.S. 1996. Mastits in ewes: the compendium for continuous education for veterinarian practice veterinarian. Food Anim. 18: 582-591.

Komine Y., Komine K., Kai K., Itagai M., Kuroishi T., Aso H., Obara Y. \& Kumagai K.L. 2006. Effect of combination therapy with lactoferrin and antibiotics against Staphylococcal mastitis on dryng cows. J. Vet. Med. Sci. 68:205-211.

Laemmli U.K. 1970. Cleavage of structural proteins during the assembly of the head of bacteriophage T4. Nature 227:680-685.

Leitner G., Merinc U., Krifucksa O., Bluma S., Rivasd A.L. \& Silanikove N. 2012. Effects of intra-mammary bacterial infection with coagulase negative staphylococci and stage of lactation on shedding of epithelial cells and infiltration of leukocytes into milk: comparison among cows, goats and sheep. Vet. Immunol. Immunopathol. 147:202-210.

Mehra R., Marnila P. \& Korhonen H. 2006. Milk immunoglobulins for health promotion. Int. Dairy J. 16:1261-1271.

Menzies P.I. \& Ramanoon S.Z. 2001. Mastitis of sheep and goats. Vet. Clin. North Am., Food Anim. Pract. 1:333-358.

Naccari F., Martino D., Giofrè F., Passantino A. \& De Montis P. 2003. Therapeutic efficacy of tilmicosin in ovine mammary infections. Small Rumin. Res. 47:1-9.

National Mastitis Council 1990. Microbiological procedures for the diagnosis of bovine udder infection. 3rd ed. NMC, Arlington. 34p.

Nudda A., Feligini M., Battacone G., Macciotta N.P.P. \& Pulina G. 2003. Effects of lactation stage, parity, $\alpha$-lactoglobulin genotype and milk SCC on whey protein composition in Sarda dairy ewes. Ital. J. Anim. Sci. 2:29-39.

Oliveira V.L.M. 2006. Aspectos do leite e mastite em ovinos da raça Santa Inês em Sergipe. Dissertação de Mestrado em Agroecossistemas, Núcleo de Pesquisa e Pós-Graduação e Estudos em Recursos Naturais, Universidade Federal de Sergipe, Aracaju, SE. 70p.

Paape M.J., Capuco A.V. \& Guidry A.J. 1995. Morfology, function and adaptation of mammary cells in normal and disease states. J. Anim. Sci. 73:1-17.

Prosser C.G. \& Mclaren R.D. 1997. Effect of atropine on milk protein yield by dairy cows with different $\beta$-lactoglobulin phenotypes. J. Dairy Sci. 80:1281-1287.

Pyörälä S., Hovinen M., Simojoki H., Fitzpatrick J., Eckersall P.D. \& Orro T. 2011. Acute phase proteins in milk in naturally acquired bovine mastitis caused by different pathogens. Vet. Rec. 168:535.

Quinn P.J., Carter M.E., Markey B. \& Carter G.R. 1994. Clinical Veterinary Microbiology. Mosby, Philadelphia. 648p.

Raimondo R.F.S., Miyiashiro S.I., Strangnolo C.R. \& Birgel Junior E.H. 2011. Efeito da infecção intramamária no proteinograma do leite de cabras. Anais IX Congresso Brasileiro de Buiatria, Botucatu. Vet. Zootec. 3(Supl.):1048-1052.

Rainard P. 1986. Bacteriostasis of Escherichia coli by bovine lactoferrin, transferring and immunoglobulins (IgG1, IgG2, IgGM) acting alone or in combination. Vet. Microbiol. 11:103-115. 
Rainard P. \& Riollet C. 2006. Innate immunity if the bovine mammary gland. Vet. Res. 37:369-400.

Sant'ana V.A.C. 2004. Proteinograma do leite de vacas: padrões e variabilidade. Tese de Doutorado, Universidade de São Paulo, São Paulo, SP. $161 \mathrm{p}$.

Santos R.A., Mendonça C.L., Afonso J.A.B. \& Simão L.C.V. 2007. Aspectos clínicos e características do leite em ovelhas com mastite induzida experimentalmente com Staphylococcus aureus. Pesq. Vet. Bras. 27: 6-12.

Sampaio I.B.M. 2007. Estatística Aplicada à Experimentação Animal. 3aㅡ ed. FEP-MVZ Editora, Belo Horizonte. 265p.

Schalm O.W., Carrol E.J. \& Jain N.C. 1971. Bovine Mastitis. Lea and Febiger, Philadelphia. 360p.

Shamay A., Homans R., Fuerman Y., Levin I., Barash H., Silanikove N. \& Mabjeesh S.J. 2005. Expression of albumin in nonhepatic tissues and its synthesis by the bovine mammary gland. J. Dairy Sci. 88:569-576.
Shirazi-Beheshtiha S.H., Safi S., Rabbani V., Bolourchi M., Ameri M. \& Khansari M.R. 2012. The diagnostic value of determination of positive and negative acute phase proteins in milk from dairy cows with subclinical mastitis. Comp. Clin. Pathol. 21:999-1003.

Smith K.L. \& Schanbacher F.L. 1977. Lactoferrin as a factor of resistance to infection of the bovine mammary gland. J. Am. Vet. Med. Assoc. 170:1224-1227.

Summer A., Malacarne M., Sandri S., Formaggioni P., Mariani P. \& Franceschi P. 2012. Effects of somatic cell count on the gross composition, protein fractions and mineral content of individual ewe's milk. Afr. J. Biotechnol. 11:16377-16381.

Suojala L., Orro T., Järvinen H., Saatsi J. \& Pyörälä S. 2008. Acute phase response in two consecutive experimentallt induce E. coli intramammary infections in dairy cows. Acta Vet. Scand. 50:18.

Urech E. \& Puhan Z. 1999. Changes in milk protein fraction as affected by subclinical mastitis. J. Dairy Sci. 82:2402-2411. 